\title{
A NOTE ON GRANDIDIERITE FROM FORT DAUPHIN, MADAGASCAR
}

\author{
Oleg v. Knorring *, Th. G. Sahama ** and Martti Lehtinen ** \\ * Dept. of Geology, Leeds University, U. K. \\ ** Dept. of Geology, University of Helsinki, Finland
}

\begin{abstract}
Chemical, optical and X-ray data are given for the grandidierite from Fort Dauphin, Madagascar. The crystal form of the mineral was studied. Infrared absorption data indicate boron to be in a threefold coordination. The simplified formula $\mathrm{MgAl}_{3}\left(\mathrm{BO}_{3}\right)\left(\mathrm{SiO}_{4}\right) \mathrm{O}_{2}$ is proposed.
\end{abstract}

Accurate optical, chemical and X-ray data have been presented by McKie (1965) for the mineral grandidierite from Madagascar described by Lacroix (1922). His data apply to the mineral from a grandidierite-biotite rock from Sakatelo, Madagascar. He showed that the boron content is considerably higher than that originally found by Lacroix and suggested that boron probably occurs in a fourfold coordination. No crystal structure determination is known to the authors.

On a visit to Madagascar in 1967 the first two authors were able to obtain some specimens of a grandidierite-bearing rock from the Fort Dauphin area at the southern end of Madagascar. No closer details of the locality are known.

In the specimens available for this study, grandidierite is associated with colorless diopside, partially altered phlogopite and black spinel (bluish in thin section). Diopside was identified by $\mathrm{X}$-ray powder pattern from which the following unit cell data were calculated: $a_{0}=9.75 \AA$, $b_{0}=8.92 \AA, c_{0}=5.26 \AA$ (all $\left.\pm 0.01 \AA\right)$ and $\beta=$ $105^{\circ} 50^{\prime} \pm 10^{\prime}$. 'These values are fairly close to those for pure diopside given by Clark et al. (1962).

In a hand specimen grandidierite is blue in color. The crystals are mostly poorly developed and often bent along the $c$-axis. The dominating faces are $\{010\}$ and $\{100\}$ with a tabular habit parallel to $(010)$. Several prism faces are observable. Terminal faces are rare. In a couple of crystals, however, a fair number of pyramidal faces could be found. Fig. 1 presents a combination of those faces which could be identified in the crystals available. Basal plane (001) was not identified. Perfect cleavage parallel to (100).

Refractive indices (sodium light): $\alpha=1.580$, $\beta=1.619, \quad \gamma=1.620$ (all \pm 0.001 ). Optically negative. $2 V_{\alpha}=24^{\circ} \pm 1^{\circ}$ (universal stage conoscope). Clear dispersion of the optic axial angle with $v>r$. The pleochroism is seen only in thick sections with $\alpha$ pale blue, $\beta$ yellowish 


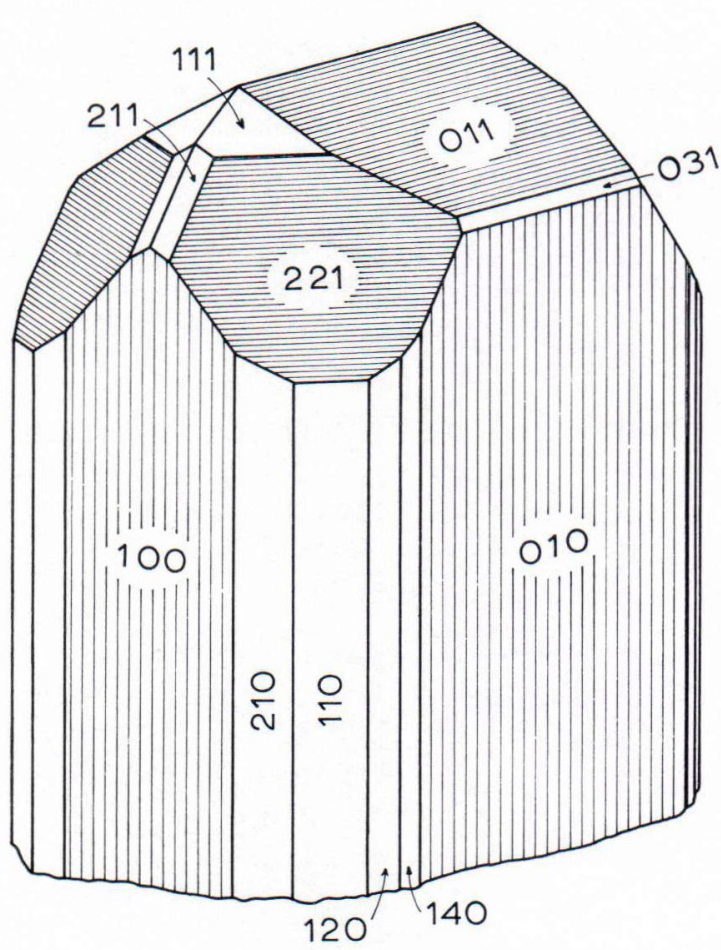

Fig. 1. Crystal habit of grandidierite.

brown, $\gamma$ deep blue. Absorption: $\gamma>\alpha>\beta$. The mineral exhibits a beautiful dichroism, deep blue when viewed along the $c$-axis and yellowish blue perpendicular to the $c$-axis. Optical orientation: $a\|\alpha, b\| \gamma, c \| \beta$. These data agree fairly well with those presented by McKie or by Lacroix except that the refractive indices of the Fort Dauphin mineral (this paper) are lower than those reported by these authors. The difference is probably due to the low iron content found for the Fort Dauphin grandidierite.

The X-ray powder pattern (Philips Norelco, filtered $\mathrm{Cu}$ radiation, $\mathrm{Si}$ standard) is very similar to that summarized by McKie and need not be reproduced here. The unit cell dimensions were calculated from the reflections 211, 031, 400, 231, 040 and 510 with the results: $a_{0}=$ $10.963 \AA, b_{0}=10.326 \AA, c_{0}=5.758 \AA$ (all \pm $0.003 \AA)$. The following single crystal precession photographs were taken: c-zero, -first and -second layer, $a$ - and $b$-zero layer. In agreement with the observation by McKie, the systematic extinctions yield the space group $P_{n a 2_{1}}$ or $P_{n a m}$. A distinction between these two space groups could not be made.

The infrared absorption spectrum of the chemically analyzed grandidierite material was recorded with a Leitz double beam infrared spectrophotometer using potassium bromide and sodium chloride optics and the $\mathrm{KBr}$ pressed pellet technique. Details of the technique have been given by Sahama and Lehtinen (1968). The spectrophotometer tracing illustrating the infrared absorption spectrum of grandidierite is reproduced in Fig. 2.

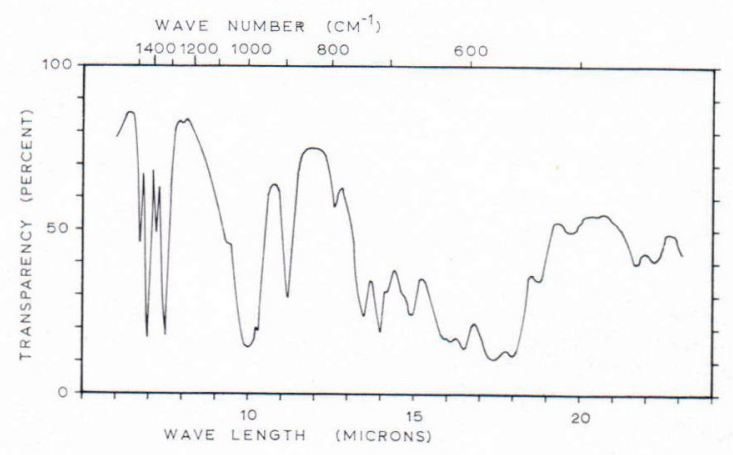

Fig. 2. Spectrophotometer tracing illustrating the infrared absorption spectrum of grandidierite from Fort Dauphin, Madagascar.

Moenke (1962) pointed out that the vibration frequences in the $\mathrm{SiO}_{4}$ and $\mathrm{BO}_{4}$ groups overlap thus making it very difficult to identify a tetrahedrally coordinated boron in borosilicates. On the other hand, according to Moenke, the vibration frequences of the $\mathrm{BO}_{3}$ group occur in a range of wave numbers higher than that arising from the $\mathrm{SiO}_{4}$ or $\mathrm{BO}_{4}$ groups. For silicate structures free from boron no bands occur above the upper limit of the $\mathrm{SiO}_{4}$ vibration, viz., ca. $1250 \mathrm{~cm}^{-1}$, and below the $\mathrm{H}_{2} \mathrm{O}$ band at about $1640 \mathrm{~cm}^{-1}$. Any bands of a borosilicate absorption spectrum occurring in the range $1640-1250 \mathrm{~cm}^{-1}$ would be indicative of a threefold coordinated boron. 
TABLE 1

Chemical composition of the grandidierite from Fort Dauphin, Madagascar. Analysis by Oleg v. Knorring

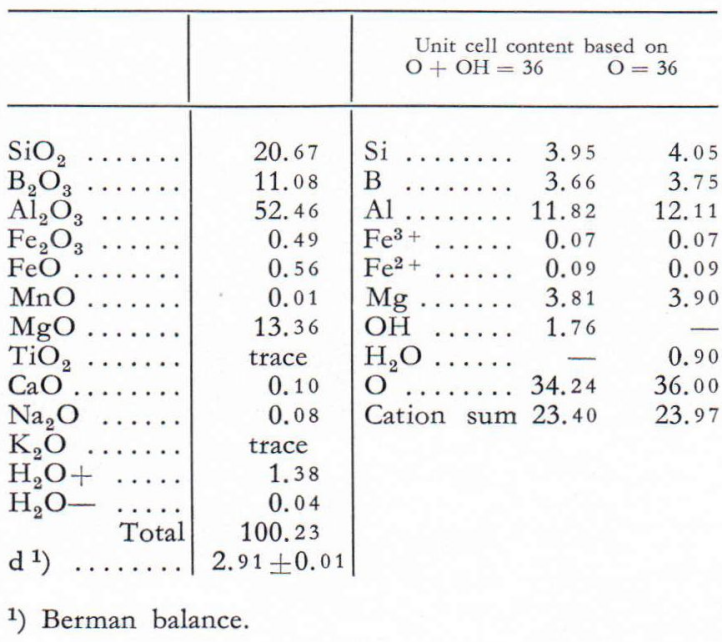

In the range indicated, Fig. 2 shows four sharp bands at about $1465 \mathrm{~cm}^{-1}$ (medium intensity), $1415 \mathrm{~cm}^{-1}$ (strong), $1370 \mathrm{~cm}^{-1}$ (medium) and $1315 \mathrm{~cm}^{-1}$ (strong), respectively. Accordingly, if the view presented by Moenke is accepted, the grandidierite structure must contain threefold coordinated boron. Any interpretation of the crystal structure of grandidierite should not neglect this evidence offered by the infrared absorption spectrum.

Some of the grandidierite material available was purified by centrifuging in heavy liquids. The fraction which amounted to several grams was tested under the microscope and was found to be virtually pure. This pure material was subjected to chemical analysis with the result summarized in Table 1.

Both grandidierite published by McKie and that studied by the authors contain only minute amounts of calcium and alkalies. Therefore, the relatively large amounts of these elements originally reported by Lacroix are considered either anomalous to the mineral or due to contamination of the analyzed material. It seems justified to neglect the calcium and the alkalies in judging the grandidierite composition.

From the chemical composition, density and unit cell volume of the Fort Dauphin grandidierite the sum $(\mathrm{O}+\mathrm{OH})$ is calculated to 35.80 , sufficiently close to the theoretical value 36 . In the analysis of the Sakatelo grandidierite made by Mr. J. H. Scoon (McKie, op. cit.) $\mathrm{H}_{2} \mathrm{O}+$ was not determined. The total given indicates that the content of $\mathrm{H}_{2} \mathrm{O}+$ must have been low. In the Fort Dauphin grandidierite of this paper the $\mathrm{H}_{2} \mathrm{O}+$ content is not negligible. Therefore, the unit cell content in Table 1 is interpreted in two ways: either assuming that $\mathrm{OH}$ replaces $\mathrm{O}$ and the sum $(\mathrm{O}+\mathrm{OH})$ is 36 or regarding $\mathrm{H}_{2} \mathrm{O}+$ as non-essential and taking $\mathrm{O}=36$. In both cases the simplified formula approaches

$$
4 \mathrm{MgAl}_{3}\left(\mathrm{BO}_{3}\right)\left(\mathrm{SiO}_{4}\right) \mathrm{O}_{2}
$$

in which $\mathrm{Mg}$ and $\mathrm{Al}$ are replaced by $\mathrm{Fe}$ to a very minor extent, a small number of the boron positions are vacant and $\mathrm{O}$ may be partly replaced by $\mathrm{OH}$. The iron content of the Fort Dauphin mineral is lower than that reported by McKie for the Sakatelo and by Lacroix for his original Andrahomana grandidierite. This fact accounts for the relatively low refractive indices and for the low density of the Fort Dauphin mineral. The slightly low density may be partly due to more or less open cracks in the pieces used for measurement with the Berman balance. 


\section{REFERENCES}

Clark Jr., Sydney P., Schatrer, J. F. and de Neufville, John (1962) Phase relations in the system $\mathrm{CaMg} \mathrm{Si}{ }_{2} \mathrm{O}_{2}-\mathrm{CaAl}_{2} \mathrm{SiO}_{6}-\mathrm{SiO}_{6}$ at low and high pressure. Ann. Rept. Geophys. Lab., Carnegie Inst. Wash. Yearb. 61, p. 59.

Lacrorx, A. (1922) Minéralogie de Madagascar, T. 1, p. 393.

McKie, Duncan (1965) The magnesium aluminium borosilicates: kornerupine and grandidierite. Min. Mag., vol. 34, p. 346.
Moenke, Horst (1962) Nachweis von $\mathrm{BO}_{3^{-}}$und $\mathrm{BO}_{4^{-}}$ Gruppen in den häufigsten natürlich gebildeten Silikaten. Silikattechnik, Bd. 13, S. 287.

Sahama, Th. G. and Lehtinen, Martti (1968) Infrared absorption of melilite. C. R. Soc. géol. Finlande, No 39, p. 29.

Manuscript received, August 26, 1968. 